Mercator, Fortaleza, v. 16, e16018, 2017.

DOI: https://doi.org/10.4215/rm2017.e16018

ISSN: $1984-2201$

Copyright @ 2002, Universidade Federal do Ceará

\title{
SURFACE TEMPERATURE AND ALBEDO IN THE ILHA SOLTEIRA REGION, SÃO PAULO
}

GOMES, Heliofabio Barros; ${ }^{\text {; }}$ CAVALCANTE, Lucas Barbosa; ${ }^{\text {b }}$ SILVA JUNIOR, Rosisberto Salustiano da; ${ }^{c}$ SANTOS, Maurilio Neemias dos; ${ }^{d}$

\begin{abstract}
(a) Phd. in Meteorology, Instituto de Ciências Atmosféricas (ICAT/UFAL). http://lattes.cnpq.br/5514144631922874 (b) MSc.in Meteorology, Instituto de Ciências Atmosféricas (ICAT/UFAL). http://lattes.cnpq.br/1201692883506898 (c) Phd. in Meteorology, Instituto de Ciências Atmosféricas (ICAT/UFAL). http://lattes.cnpq.br/1798232201205174 (d) MSc. in Meteorology, Instituto de Ciências Atmosféricas (ICAT/UFAL). http://lattes.cnpq.br/8873800903145303
\end{abstract}

\section{(*) CORRESPONDING AUTHOR}

Address: ICAT-UFAL, Av. Lourival Melo Mota, s/n, Tabuleiro dos Martins, Maceió - AL, Brasil. CEP 57072-900. Tel: (+55 82) $3214-1369$ E-mail: heliofabio@icat.ufal.br

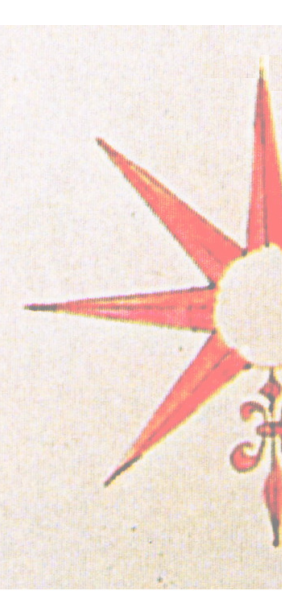

\begin{abstract}
The main purpose was to perform a dynamic analysis in the fields of soil heat flux, albedo and surface temperature, with a 10 -year interval, for the region of Ilha Solteira. The data used were obtained through multispectral images from TM Landsat 5's sensor, corresponding to orbit 222, point 74, for May 13, 2000 and April 10, 2011. Using the results obtained, the surface albedo was estimated with minimum values of $3.7 \%$ and a maximum of $53.2 \%$ for May 13, 2000 and minimum values of 2.0 and a maximum of $58.4 \%$ for April 10 2011, showing an increase in the surface reflexivity of the study area. With the increase of the surface albedo, the mean surface temperature rose from $24.5^{\circ} \mathrm{C}$, in 2000 , to $25.2^{\circ} \mathrm{C}$, in 2011 , a rise of $0.7^{\circ} \mathrm{C}$. For soil heat flux, the variations were of 62.9 W.m-2 in May 13, 2000, to 58.0 W.m-2 in April 10, 2011, revealing a greater heat retention in the soil.
\end{abstract}

Keywords: Remote Sensing, Vegetation, Surface Temperature.

\section{RESUMO/RESUMEN}

\section{TEMPERATURA DA SUPERFÍCIE E ALBEDO NA REGIÃO DE ILHA SOLTEIRA, SÃO PAULO}

O principal objetivo foi realizar análise dinâmica nos campos de fluxo de calor no solo, albedo e temperatura da superfície com intervalo de 10 anos, para a região de Ilha Solteira. Os dados utilizados foram obtidas através de imagens multiespectrais do sensor TM Landsat 5 correspondentes a órbita 222, ponto 74, para 13/05/2000 e 10/04/2011. Mediante os resultados obtidos, o albedo da superfície foi estimado com valores mínimos de $3,7 \%$ e máximos de $53,2 \%$ para o dia 13/05/2000 e valores mínimos de $2,0 \%$ e $58,4 \%$ para o dia 10/04/2011 constatando um aumento na refletividade da superfície da área de estudo. Com o aumento do albedo da superfície, o valor médio da temperatura da superfície passou de $24,5^{\circ} \mathrm{C}$, em 2000 , para $25,2^{\circ} \mathrm{C}$, em 2011, o que nos mostra uma elevação de $0,7^{\circ} \mathrm{C}$. Para o fluxo de calor no solo, as variações foram de 62,9 W.m-2 em 13/05/2000 para 58,0 W.m-2 em 10/04/2011 evidenciando uma maior retenção de calor no solo.

Palavras-chave: Sensoriamento Remoto, Vegetação, Temperatura da Superfície.

\section{TEMPERATURA DE LA SUPERFICIE Y ALBEDO EN LA REGIÓN DE ISLA SOLTERA,} SÃO PAULO

El principal objetivo fue realizar análisis dinámico en los campos de flujo de calor en el suelo, albedo y temperatura de la superficie con intervalo de 10 años, para la región de Ilha Solteira. Los datos utilizados fueron obtenidos a través de imágenes multiespectrales del sensor TM Landsat 5 correspondientes a la órbita 222 , punto 74 , para 13/05/2000 y 10/04/2011. En los resultados obtenidos, el albedo de la superficie fue estimado con valores mínimos y máximos de 3,7\% y 53,2\% para el día 13/05/2000, y valores mínimos y máximos de $2,0 \%$ y 58,4\% para el día 10/04/2011, constatando un aumento en la reflectancia de la superficie en el área de estudio. Con el aumento del albedo de la superficie, el valor medio para la temperatura de la superficie pasó de $24,5^{\circ} \mathrm{C}$, en 2000 , a $25,2^{\circ} \mathrm{C}$, en 2011 , lo que nos muestra una elevación de $0,7^{\circ} \mathrm{C}$. Para el flujo de calor en el suelo, las variaciones fueron de 62,9 W.m -2 en 13/05/2000 a 58,0 W.m -2 para el día 10/04/2011, evidenciando una mayor retención de calor en el suelo.

Palabras claves: Teledetección, Vegetación, Temperatura de la superficie. 


\section{INTRODUCTION}

The use of Orbital Remote Sensing is considered a breakthrough in the study of urban environments and ecosystems due to its ability to work on regional scales, at a low economic cost, and its functionality and speed in data collection. In addition, when compared with traditional methods, it is capable of making a permanent registration of the area or object of study with a high degree of accuracy (FERREIRA et al., 2001).

It is known that the growth of urban areas and agricultural land use modifies the characteristics of the local climate, altering the patterns and the magnitude of the interaction between solar radiation and the soil and, consequently, the energy exchange processes in the soil-plant-atmosphere system (GARTLAND, 2008).

In this context, the modifications caused by the installation of the Ilha Solteira Hydroelectric Power Plant in 1978 caused profound changes in the region of the homonymous municipality, both in its geography and in the way of life of its inhabitants and, principally, in its environmental composition. In the case of the latter, the remaining native vegetation was, for the most part, devastated during the occupation of the area, being replaced by anthropic fields and pastures (SILVA, 1991 and FREITAS-LIMA et. al., 1997). As the suppression of vegetation favors the incidence of solar rays on the surface and raises the temperature (CASTRO et. al., 2013), it is important to study the behavior of the temperature at the site and apply this information to improve agricultural productivity, as well as the urban planning of the locality (COELHO, 2004).

In this regard, the present work aims to estimate the albedo, the earth's surface temperature and the soil heat flux on two days, over a period of 11 years, for the region of Ilha Solteira/SP. To this end, data from images of Thematic Mapper's sensor aboard the satellite Landsat 5 were used in conjunction with a number of variables collected in the field and using the SEBAL algorithm (Surface Energy Balance Algorithm for Land), proposed by Bastiaanssen (1995).

\section{MATERIALS AND METHODS}

\section{AREA OF STUDY}

The study area covers the city of Ilha Solteira/SP (20²5'58'S; 51 $\left.20^{\prime} 33^{\prime \prime} \mathrm{W} ; 335 \mathrm{~m}\right)$, and is part of the Mesoregion of Araçatuba, in the administrative region of Andradina. In the state of São Paulo, it has geographical boundaries with the municipalities of Itapura, Pereira Barreto, Suzanópolis, Rubinénia and Andradina. In the state of Mato Grosso do Sul it borders the municipalities of Três Lagoas and Selvíria. It has an area of $659.4 \mathrm{Km}^{2}$ and is bathed by the Paraná River (West), and the Tietê (South) and São José dos Dourados (Center) Rivers (IBGE, 2008).

\section{CLIMATE AND VEGETATION}

The climate of the municipality is classified as tropical rainforest, characterized by summer rains and drought in winter. The annual mean temperature is $28^{\circ} \mathrm{C}$, with the mean annual maximum reaching $31^{\circ} \mathrm{C}$, and a pluviometric index of $1.300 \mathrm{~mm}$ per year (PMIS, 2014).

Formations of tropical broadleaf forest, humid forest, broadleaf forest, and cerrado compose the remaining natural vegetation. Most of this original cover was devastated during the occupation of the land and currently anthropic fields and pastures represent the main soil cover (SILVA, 1991).

\section{RADIOMETRIC DATA}

The components of the energy fluxes used to determine the spectral-temporal dynamic of the fields of soil heat fluxes, albedo and surface temperature were created from images generated by 
Thematic Mapper-TM, aboard the satellite Landsat 5, and a few additional surface data. The Landsat 5 - TM images used in the study were obtained from the DGI (Division of Images Generation) of the INPE (National Institute for Space Research), and consist of orbit 222 and point 074, obtained at approximately 12:57:50 and 13:11:53, on 13 May 2000 and 10 April 2011, respectively. These days were selected due to the absence of cloud coverage over the study area during the passage of Landsat 5 over it, as well as the images being collected in the same season (autumn) and at an interval superior to 10 years. They are composed of 07 spectral bands, whose main characteristics are described in Table 1 . The cutouts of the days selected for the study are represented in images of RGB composition for bands 4, 3, 2 of the TM sensor (figures 1a and 1b).

Table 1 - Description of the bands of the Thematic Mapper (TM) of Landsat 5, with the corresponding intervals of wavelength, calibration coefficients (minimum radiance $-\mathrm{a}$; and maximum $-\mathrm{b}$ ) and spectral irradiances at the top of the atmosphere (TOA)

\begin{tabular}{|c|c|c|c|c|c|}
\hline \multirow{4}{*}{ Description of the Bands } & \multirow{2}{*}{\multicolumn{4}{|c|}{$\frac{\text { Calibration Coefficients }\left(\mathrm{Wm}^{-2} \mathrm{~s}^{-1} \mathbf{\mathrm { m }}{ }^{-1}\right)}{\text { Processing Date }}$}} & \multirow{4}{*}{$\begin{array}{l}\text { Spectral Irradiance at the TOA } \\
\qquad \mathrm{K}_{\lambda \mathrm{i}}\left(\mathrm{Wm}^{-2} \mathrm{~m}^{-1}\right)\end{array}$} \\
\hline & & & & & \\
\hline & \multicolumn{2}{|c|}{$\begin{array}{l}\text { From 01/March/1984 to 04/ } \\
\text { May/2003 }\end{array}$} & \multicolumn{2}{|c|}{$\begin{array}{l}\text { From 05/ } \\
\text { May/2003 }\end{array}$} & \\
\hline & $\mathrm{L}_{\min }=\mathrm{a}$ & $\mathrm{L}_{\max }=\mathrm{b}$ & $\mathrm{L}_{\min }=\mathrm{a}$ & $\mathrm{L}_{\max }=\mathrm{b}$ & \\
\hline Band 1 (blue) & $-1,520$ & 152,100 & $-1,520$ & 193,000 & 1957 \\
\hline Band 2 (green) & $-2,840$ & 296,810 & $-2,840$ & 365,000 & 1826 \\
\hline Band 3 (red) & $-1,170$ & 204,300 & $-1,170$ & 264,000 & 1554 \\
\hline Band 4 (IV near) & $-1,510$ & 206,200 & $-1,510$ & 221,000 & 1036 \\
\hline Band 5 (IV medium) & $-0,370$ & 27,190 & $-0,370$ & 30,200 & 215 \\
\hline Band 6 (IV thermal) & 1,2378 & 15,303 & 1,2378 & 15,303 & - \\
\hline Band 7 (IV medium) & $-0,150$ & 14,380 & $-0,150$ & 16,500 & 80,67 \\
\hline
\end{tabular}

Fonte: Chander; Markram, 2003.

Air temperature data were collected from UNESP's station of in Ilha Solteira $\left(20^{\circ} 25^{\prime} 24,4\right.$ ' $S$; $51^{\circ} 21^{\prime} 13,1^{\prime \prime} \mathrm{W} ; 337 \mathrm{~m}$ ), and registered $23.9^{\circ} \mathrm{C}$ for 13 May 2000, and $24.8^{\circ} \mathrm{C}$ for 10 April 2011.
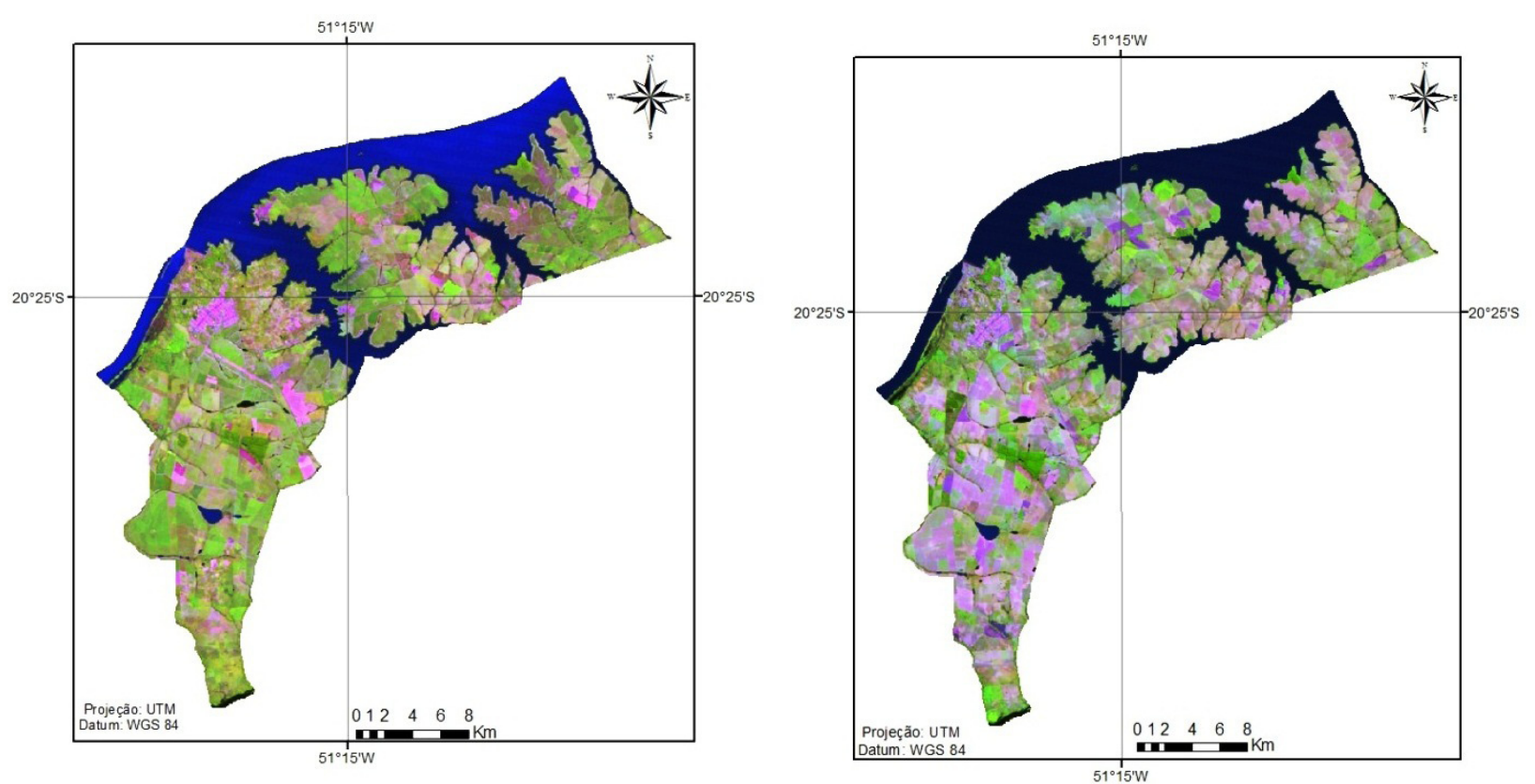

Figure 1 - Cutout of the study area in RGB composition with bands 4, 3 and 2 for (a) 13/May/2000 and (b) 10/ April/2011. 


\section{IMAGE PROCESSING}

The processing of the satellite images was performed with the ERDAS Imagine 2014 and QGIS 2.14 software, and the mathematical operations for the intra and inter spectral bands with the Model Maker tool. The TM - Landsat 5 measures the spectral radiance of each pixel in seven different spectral bands, and stores them in digital form; their intensity varies from 0 to 255 ( 8 bits). The images of the TM sensor have a spatial resolution of $30 \mathrm{~m} \times 30 \mathrm{~m}$ in bands $1,2,3,4,5$ and 7 , and of $120 \mathrm{~m} \times 120 \mathrm{~m}$ in band 6 , which must be resampled in the pre-processing in order to have the same spatial resolution of the other bands so that they will fit during the staking process. The TM sensor measures the spectral radiance of the targets and stores them in the form of gray levels or digital numbers, whose values vary from 0 to 255 ( 8 bits). The SEBAL algorithm was used for the processing and development of the images (Figure 2).

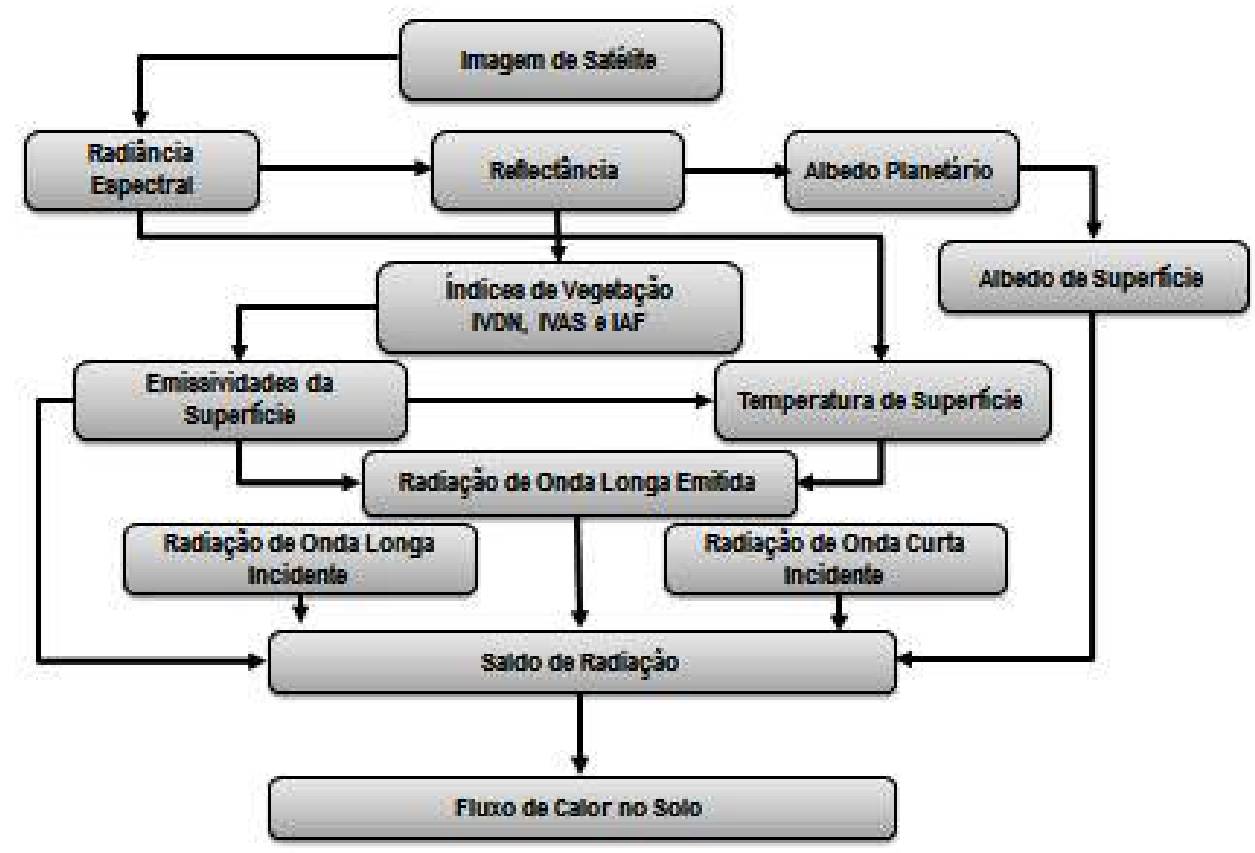

Figure 2 - Diagram of the SEBAL algorithm steps used in the study. Source: Adapted from Gomes et. al. (2009)

\section{RADIOMETRIC CALIBRATION - STEP 1}

This consists of the calculation of the spectral radiation in each band (L $\lambda \mathrm{i})$, in which the digital number of each pixel of the image is converted into monochrome spectral radiance. This radiance represents the solar energy reflected by each pixel, per area unit, time, solid angle and wavelength, measured at Landsat satellite level for bands 1, 2, 3, 4, 5, 7 and, for band 6, the calibration is carried out according to Markham and Baker (1987).

$$
\mathrm{L}_{\lambda \mathrm{i}}=\mathrm{a}_{\mathrm{i}}+\frac{\mathrm{b}_{\mathrm{i}}-\mathrm{a}_{\mathrm{i}}}{255} \mathrm{ND}
$$

Where: $a$ and $b$ are the minimum and maximum spectral radiances $\left(\mathrm{Wm}^{-2} \mathrm{sr}^{-1} \mu \mathrm{m}^{-1}\right.$, Table 1); ND is the intensity of the pixel (digital number - whole number from 0 to 255); and i corresponds to the bands $(1,2 \ldots$ and 7$)$ of the Landsat $5-$ TM satellite. 


\section{MONOCHROMATIC REFLECTANCE - STEP 2}

This was defined as being the ratio between the reflected radiation flux and the incident radiation flux, obtained according to the equation (ALLEN et. al., 2002):

$$
\rho_{\lambda \mathrm{i}}=\frac{\pi \cdot \mathrm{L}_{\lambda \mathrm{i}}}{\mathrm{k}_{\lambda_{\mathrm{i}}} \cdot \cos Z \cdot \mathrm{d}_{\mathrm{r}}}
$$

Where " $\mathrm{L} \lambda \mathrm{i}$ " is the spectral radiance of each band, $\mathrm{k} \lambda \mathrm{i}$ is the spectral solar irradiance of each band at the top of the atmosphere $\left(\mathrm{Wm}^{-2} \mu \mathrm{m}^{-1}\right.$, Table 1$), \mathrm{Z}$ is the solar zenith angle (in degrees, with $Z=90-E$, and $E=$ elevation angle) and $d r$ is the square of the ratio between the average distance Earth-Sun (ro) and the distance Earth-Sun (r) on a given day of the year (DSA) which, according to Iqbal (1983), is given by:

$$
\left(\frac{r_{o}}{r}\right)^{2}=1,000110+0.034221 \cos \Gamma+0,001280 \operatorname{sen} \Gamma+0,000719 \cos 2 \Gamma+0,000077 \operatorname{sen} 2 \Gamma
$$

Where: $\Gamma=360(\mathrm{DJ}-1) / 365$ ) (o) and DJ is the Julian day. On 24 September 2000 we had $\mathrm{DJ}=267, \mathrm{dr}=0.9935$ and $\mathrm{Z}=31.5719$ and, for 06 October 2010 we obtained $\mathrm{DJ}=279, \mathrm{dr}=$ 1.005 and $Z=26.9799$.

\section{PLANETARY ALBEDO - STEP 3}

O albedo planetário, também conhecido como albedo não corrigido, é obtido através da combinação linear das reflectâncias monocromáticas, qual seja:

$$
\alpha_{\text {toa }}=0,293 \rho_{1}+0,274 \rho_{2}+0,233 \rho_{3}+0,157 \rho_{4}+0,033 \rho_{5}+0,011 \rho_{7}
$$

Where $\rho_{1}, \rho_{2}, \rho_{3}, \rho_{4}, \rho_{5}$ e $\rho_{7}$ are the monochromatic reflectances of bands $1,2,3,4,5$ and 7 . onde são as reflectâncias monocromáticas das bandas 1, 2, 3, 4, 5 e 7.

\section{ATMOSPHERIC TRANSMISSIVITY - STEP 4}

Under clear sky conditions, it can be obtained as in Allen et. al. (2002):

$$
\tau_{\mathrm{sw}}=0,75+2 \cdot 10^{-5} \mathrm{z}
$$

Where: $\mathrm{z}$ is the altitude of each pixel, in meters, for the study area the result was a value of $\tau \mathrm{sw}=0.75858$; considering the area's average altitude of 419 meters (IBGE). For the purpose of this study, the average altitude was considered for the entirety of the study terrain, thus obtaining a constant atmospheric transmissivity for the whole area.

\section{SURFACE ALBEDO - STEP 5}

The surface albedo is the albedo corrected of atmospheric effects:

$$
\alpha=\frac{\alpha_{\text {toa }}-\alpha_{\mathrm{p}}}{\tau_{\mathrm{sw}}{ }^{2}}
$$

Where $\alpha p$ is the solar radiation reflected by the atmosphere, varying between 0.025 and 0.04 . Bastiaanssen (2000) sustains that the most suitable value for SEBAL is 0.03 . $\tau \mathrm{sw}$ is the atmosphe- 
ric transmissivity, obtained for clear sky conditions in relation to the altitude of each pixel, in an equation proposed by Allen et. al. (2002).

\section{NDVI, SAVI AND LAI - STEP 6}

The Normalized Difference of Vegetation Index, NDVI, is an important element for the study of climatic changes, using vegetation as the calculation index, attributing a determined value to the study area that will depend on the current state of the vegetation (LOPES and VALERIANO, 2010).

The Normalized Difference of Vegetation Index is obtained from the ratio between the difference of the near-infrared reflectivity ( IV $\rho$ ) and the red ( V $\rho$ ), and their sum:

$$
\mathrm{NDVI}=\frac{\rho_{\mathrm{IV}}-\rho_{\mathrm{V}}}{\rho_{\mathrm{IV}}+\rho_{\mathrm{V}}}
$$

Where $\rho_{\mathrm{IV}}$ e $\rho_{\mathrm{V}}$ correspond, respectively, to bands 4 and 3 of Landsat 5 - TM.

The NDVI acts as a sensitive indicator of the amount and condition of green vegetation. Its values vary from -1 to +1 . For surfaces with some vegetation, the NDVI varies from 0 and 1 ; for water and clouds the NDVI is generally lower than zero.

The SAVI (Soil-adjusted Vegetation Index) is an index that seeks to mitigate the "background" effects of the soil. It is calculated using the following equation (HUETE, 1988):

$$
\mathrm{SAVI}=\frac{(1+\mathrm{L})\left(\rho_{\mathrm{IV}}-\rho_{\mathrm{V}}\right)}{\left(\mathrm{L}+\rho_{\mathrm{IV}}+\rho_{\mathrm{V}}\right)}
$$

The LAI, Leaf Area Index is defined by the ratio between the leaf areas of all the vegetation per unit of area occupied by this vegetation. This index is a good indicator of the biomass of each image pixel, being calculated by the empirical equation proposed by Allen et. al. (2002):

$$
\mathrm{IAF}=-\frac{\ln \left(\frac{0,69-\mathrm{SAVI}}{0,59}\right)}{0,91}
$$

\section{EMISSIVITY - STEP 7}

The inverted Planck equation is used to obtain the surface temperature, valid for a blackbody. As each pixel does not emanate electromagnetic radiation as a blackbody, it is necessary to introduce each pixel's emissivity into the spectral domain of the thermal band ${ }^{\mathrm{NB}}$, namely: $10.4-12.5$ $\mu \mathrm{m}$. In turn, when calculating the long wave radiation emitted by each pixel, the emissivity in the broadband domain $(5-100 \mu \mathrm{m})$ is considered. According to Allen et. al. (2002), the emissivity $\varepsilon_{\mathrm{NB}} \quad(3.9)$ and $\varepsilon 0(3.10)$ can be obtained, for NDVI $>0$ and $\mathrm{IAF}<3$, by:

$$
\begin{aligned}
& \varepsilon_{\mathrm{NB}}=0,97+0,00331 \mathrm{IAF} \\
& \varepsilon_{0}=0,95+0,01 \mathrm{IAF}
\end{aligned}
$$

For pixels with $\mathrm{IAF} \geq 3, \varepsilon_{\mathrm{NB}}=\varepsilon_{0}=0,98$. For bodies of water $(\mathrm{NDVI}<0)$, in the case of Sobradinho Lake and the São Francisco Riverbed, Silva \& Cândido (2004) used values of $\varepsilon_{\mathrm{NB}}=0,99$ e $\varepsilon_{0}=0,985$, according to Allen et. al. (2002). 


\section{SURFACE TEMPERATURE - STEP 8}

The spectral radiance of the thermal band $\mathrm{L}_{\lambda, 6}$ and the emissivity $\varepsilon_{\mathrm{NB}}$ obtained in the previous step were used to obtain the surface temperature (Ts). Thus, the surface temperature $(\mathrm{K})(3.11)$ is obtained through the following expression:

$$
\mathrm{T}_{\mathrm{s}}=\frac{\mathrm{K}_{2}}{\ln \left(\frac{\varepsilon_{\mathrm{NB}} \mathrm{K}_{1}}{\mathrm{~L}_{\lambda, 6}}+1\right)}
$$

Where $\mathrm{K}_{1}=607,76 \mathrm{Wm}^{-2} \mathrm{sr}^{-1} \mu \mathrm{m}^{-1}$ e $\mathrm{K}_{2}=1260,56 \mathrm{~K}$ are calibration constants of the thermal band of Landsat 5 - TM (ALLEN et. al., 2002). In May 13, 2000, the result obtained was Ta 297.05 $\mathrm{K}$, and for April 10, 2011 it was $297.95 \mathrm{~K}$.

\section{OUTGOING LONGWAVE RADIATION - STEP 9}

The outgoing longwave radiation emitted from the surface $\mathrm{R}_{\mathrm{L} \uparrow}\left(\mathrm{Wm}^{-2}\right)$ is obtained through the Stefan-Boltzmann equation:

$$
\mathrm{R}_{\mathrm{L} \uparrow}=\varepsilon_{0} \cdot \sigma \cdot \mathrm{T}_{\mathrm{s}}^{4}
$$

Where $\varepsilon_{0}$ represents the emissivity of each pixel, $\sigma$ is the Stefan-Boltzmann constant $\left(\sigma=5,67.10^{-8} \mathrm{Wm}^{-2} \mathrm{~K}^{-4}\right)$ and $\mathrm{T}_{\mathrm{s}}$ is the surface temperature $(\mathrm{K})$

\section{INCIDENT SHORTWAVE RADIATION - STEP 10}

The incident shortwave radiation $\mathrm{R}_{\mathrm{s} \downarrow}\left(\mathrm{Wm}^{-2}\right)$ is the flux of direct and diffuse solar radiation that hits the Earth's surface, which, for clear sky conditions is given by the following expression (ALLEN et. al., 2002):

$$
\mathrm{R}_{\mathrm{s} \downarrow}=\mathrm{S} \cdot \cos Z \cdot \mathrm{d}_{\mathrm{r}} \cdot \tau_{\mathrm{sw}}
$$

Where $\mathrm{S}$ is the solar constant $\left(1367 \mathrm{Wm}^{-2}\right), \mathrm{Z}$ is the solar zenith angle, $\mathrm{d}_{\mathrm{r}}$ is the inverse of the square of the relative Earth-Sun distance, and $\tau$ sw is the atmospheric transmissivity. $R_{s \downarrow}$ can be considered constant throughout the study area, when the area is small in size.

\section{INCIDENT SHORTWAVE RADIATION - STEP 11}

The incident shortwave radiation emitted by the atmosphere towards the surface $R_{L \downarrow}\left(\mathrm{Wm}^{-2}\right)$ can be calculated by the Stefan-Boltzmann equation:

$$
\mathrm{R}_{\mathrm{L} \downarrow}=\varepsilon_{\mathrm{a}} \cdot \sigma \cdot \mathrm{T}_{\mathrm{a}}^{4}
$$

Where $\varepsilon_{\mathrm{a}}$ represents the atmospheric emissivity obtained by: $\varepsilon_{\mathrm{a}}=0,85 \cdot\left(-\ln \tau_{\mathrm{sw}}\right)^{0,09}$ (ALLEN et. al., 2002), $\sigma$ is the Stefan-Boltzmann constant, and is the air temperature (K). 
Onde é a emissividade atmosférica obtida por: (ALLEN et al., 2002), é a constante de Stefan-Boltzman e $\mathrm{T}_{\mathrm{a}}$ é a temperatura do ar $(\mathrm{K})$.

\section{RADIATION BALANCE - STEP 12}

The radiation balance for surface $\mathrm{Rn}\left(\mathrm{Wm}^{-2}\right)$ is calculated using the following equation of surface radiation balance:

$$
R n=R_{s \downarrow}-\alpha R_{s \downarrow}+R_{L \downarrow}-R_{L \uparrow}-\left(1-\varepsilon_{o}\right) R_{L \downarrow}
$$

Where $\mathrm{R}_{s \downarrow}$ is the incident shortwave radiation, $\alpha$ is the corrected albedo of each pixel, $R_{L \downarrow}$ is the longwave radiation emitted by the atmosphere in the direction of each pixel, is the longwave radiation emitted by each pixel, and $\varepsilon_{o}$ is the emissivity of each pixel.

\section{SOIL HEAT FLUX (G) - STEP 13}

The soil heat flux, $\mathrm{G},\left(\mathrm{Wm}^{-2}\right)$ can be obtained according to the empirical equation developed by Bastiaanssen (2000), which represents values close to mid-day:

$$
\mathrm{G}=\left[\frac{\mathrm{T}_{\mathrm{s}}}{\alpha}\left(0,0038 \alpha+0.0074 \alpha^{2}\right)\left(1-0,98 \mathrm{NDVI}^{4}\right)\right] \mathrm{Rn}
$$

Where $\mathrm{T}_{\mathrm{s}}$ is the surface temperature $\left({ }^{\circ} \mathrm{C}\right), \alpha$ is the surface albedo, and NDVI is the Normalized Difference of Vegetation Index, all computed pixel by pixel. For the purpose of correction of the heat flux values for bodies of water $(\mathrm{NDVI}<0)$, the following expression can be utilized $\mathrm{G}=0.3 \mathrm{Rn}$, used by Silva \& Cândido (2004) and $\mathrm{G}=0.5 \mathrm{Rn}$, according to Allen et. al., (2002) for deep lakes.

\section{RESULTS AND DISCUSSION}

\section{SURFACE ALBEDO}

Table 2 shows the Instantaneous Surface Albedo values of the region for the days under study. For May 13, 2000, the values found presented a mean of $15.1 \%$, a minimum of $3.7 \%$, a maximum of $53.2 \%$ and a standard deviation of \pm 3.8 . April 10,2011 , presented mean values of $14.0 \%$, a

\begin{tabular}{|c|c|c|c|c|}
\hline Surface Albedo (\%) & Minimum & Maximum & Mean & Standard Deviation \\
\hline 13.May.2000 & 3.7 & 53.2 & 15.1 & \pm 3.8 \\
\hline 10.April.2011 & 2.0 & 58.4 & 14.0 & \pm 3.2 \\
\hline
\end{tabular}
maximum of $58.4 \%$, a minimum of $2.0 \%$ and a standard deviation of \pm 3.2 .

High albedo values can identify surfaces that are smooth, dry and light colored, and lower values are associated with surfaces that are rough, humid and dark colored (LOPES et. al., 2007). In turn, Querino et. al., (2006) found mean annual albedo values of 13\% for regions of forests, and of $18 \%$ for pastures. Authors such as Sellers (1969) and Arya (1998) found albedos for orchards varying between $15 \%$ and $20 \%$, and wheat and rice of $10 \%$ to $25 \%$. The albedo of water varies 
from $3 \%$ to $10 \%$ for a small zenith angle and $10 \%$ to $50 \%$ for a large zenith angle; the values for exposed dry soil were $20 \%$ to $35 \%$ and exposed humid soil $10 \%$ to $20 \%$.

In figure 3(a) and table 3, for May 13, 2000, it was observed that the most common albedo values ranged between $15.0 \%$ and $18.0 \%$, shown in the medium blue color, which represented $43.29 \%$ of the image pixels. The second largest type of occurrence was the interval represented by the light blue color, between 18.0 and $21.0 \%$, and with $20.67 \%$ of the occurrences. The values referring to bodies of water had indexes between $3.0 \%$ and $12.0 \%$, representing $25.57 \%$ of the data obtained.

For figure 3(b) and table 3, referring to April 10, 2011, it was observed that the highest value remained the interval between $15.0 \%$ and $18.0 \%$, the medium blue color, with $43.98 \%$ of the pixels. The second most frequent occurrence was the interval between $12.0 \%$ and $15.0 \%$, with $24.02 \%$ of the data. Bodies of water moved from the interval between $6.0 \%$ and $9.0 \%$, light pink color, to the interval between $9.0 \%$ and $12.0 \%$, dark pink color, representing $26.45 \%$ of the total.
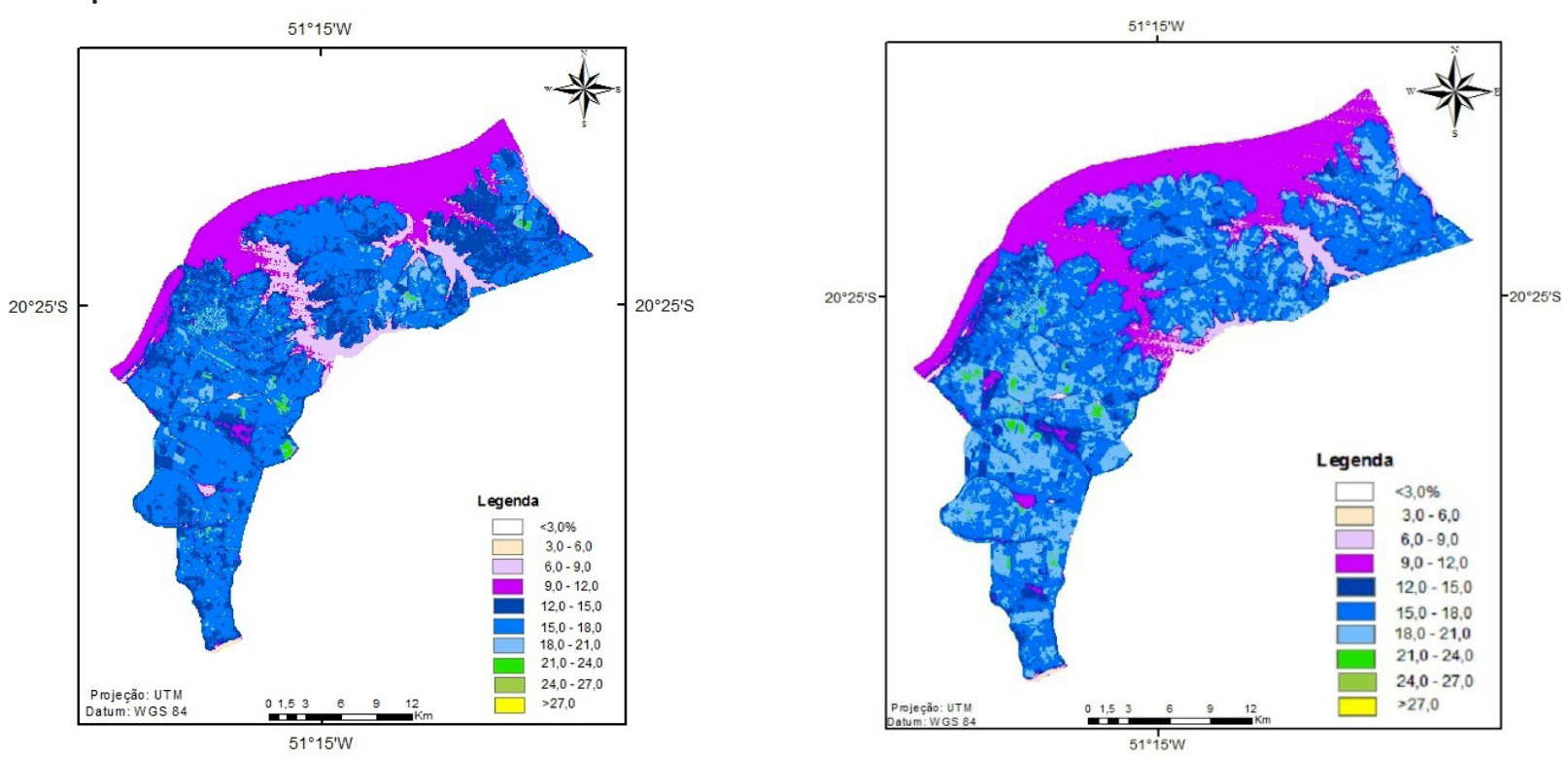

Figure 3 - Images classified of the Surface Albedo (in \%), (a) for 13/May/2000 and (b) for 10/April/2011

Table 3 - Distribution of surface albedo values (in \%) for 13/May/2000 and 10/April/2011

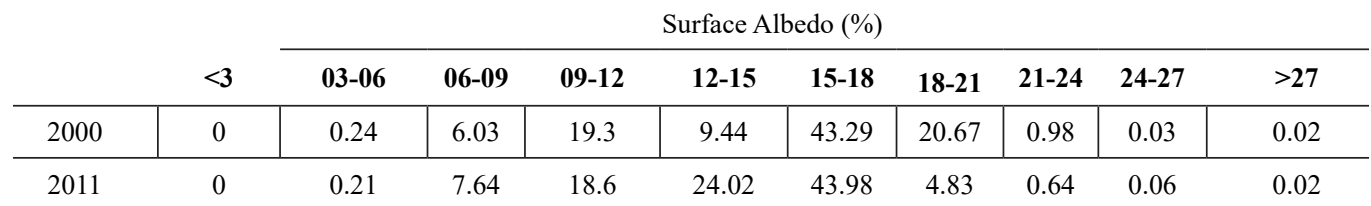

For the analysis of the two days studied, the Surface Albedo registered a variation of $9.7 \%$ in maximum values, $-7.2 \%$ in the mean, and $46 \%$ in the minimum. The increase of the maximum values may have been caused by growth in urbanization or by the replacement of native forest areas by pastures or agricultural crops. In turn, the decrease of the mean may have been caused by the occurrence of rainfall in the days prior to the passage of the satellite. Below, figure 4 shows the comparative histogram of the surface albedo frequencies for the two images used. 


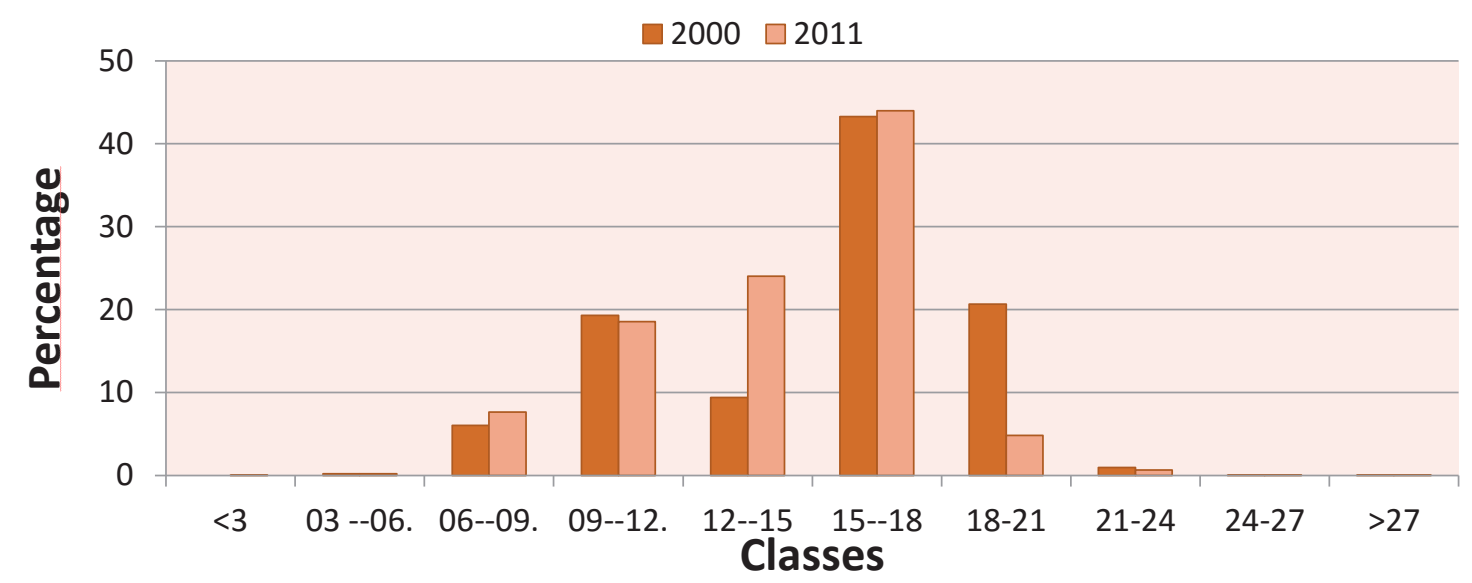

Figure 4 - Comparative histogram of Surface Albedo frequencies for the two images used

\section{a) Surface Temperature}

For May 13, 2000, the surface temperature values found presented a mean of $24.5^{\circ} \mathrm{C}$, with a minimum of $18.0^{\circ} \mathrm{C}$, a maximum of $34.5^{\circ} \mathrm{C}$ and a standard deviation of \pm 2.2 . In turn, April 10, 2011, presented mean values of $25.2^{\circ} \mathrm{C}$, a maximum of $40.5^{\circ} \mathrm{C}$, a minimum of $21.1^{\circ} \mathrm{C}$ and a standard deviation in \pm 2.1 . Table 4 shows the estimated values for surface temperature..

\begin{tabular}{|c|c|c|c|c|}
\hline Surface Temperature $(\%)$ & Minimum & Maximum & Mean & Standard Deviation \\
\hline 13.May.2000 & 18.0 & 34.5 & 24.5 & \pm 2.2 \\
\hline 10.April.2011 & 21.1 & 40.5 & 25.2 .0 & \pm 2.1 \\
\hline
\end{tabular}

For locations with water, while studying the Botucatu/SP region Mashiki (2012) found mean temperatures of $20.9^{\circ} \mathrm{C}$, whilst Bias et. al. (2003) found values between $17^{\circ} \mathrm{C}$ and $18^{\circ} \mathrm{C}$. Gomes et. al. (2009), for the region of Santa Rita do Passa Quatro/SP found values between $20.0^{\circ} \mathrm{C}$ and $24.1^{\circ} \mathrm{C}$ for flooded plantation areas and between $26.9^{\circ} \mathrm{C}$ and $25.0^{\circ} \mathrm{C}$ for locations with sugarcane plantations. Lima (2008), near Campo Grande/MS, found temperatures for pasture areas from $19^{\circ} \mathrm{C}$ to $29^{\circ} \mathrm{C}$, for temporary crops from $19^{\circ} \mathrm{C}$ to $29^{\circ} \mathrm{C}$, for forest areas from $13^{\circ} \mathrm{C}$ to $17^{\circ} \mathrm{C}$ and for silviculture between $14^{\circ} \mathrm{C}$ and $17^{\circ} \mathrm{C}$. According to Godoy et. al. (2009), locations of exposed soil ranged from $25^{\circ} \mathrm{C}$ to $48^{\circ} \mathrm{C}$. The differences between forest areas outside the urban perimeter and those located in central regions were of up to $20^{\circ} \mathrm{C}$ (COSTA et. al., 2009).

Figure 5(a) and table 5 show the values found for surface temperature on May 13, 2000. The greatest occurrence was for values lower than $22^{\circ} \mathrm{C}$, the dark blue color, answering for $24.1 \%$ of the image pixels and corresponding, largely, to regions with water. The second largest interval was the one with values that ranged between $24^{\circ} \mathrm{C}$ and $25^{\circ} \mathrm{C}$, answering for $13.9 \%$, the light green color. In turn, the smallest index was for temperatures higher than $33^{\circ} \mathrm{C}$, in dark red.

Figure 5(b) and table 5 represent the behavior of surface temperature for April 10, 2011, in which the greatest frequency was the index between $25^{\circ} \mathrm{C}$ and $26^{\circ} \mathrm{C}$, in medium green, answering for $21.0 \%$. The second largest interval found ranged between $22^{\circ} \mathrm{C}$ and $23^{\circ} \mathrm{C}$, in light green, answering for $19.0 \%$ of the data. The smallest index was for temperatures between $32^{\circ} \mathrm{C}$ and $33^{\circ} \mathrm{C}$, in light red, with $0.3 \%$ of the pixels. 

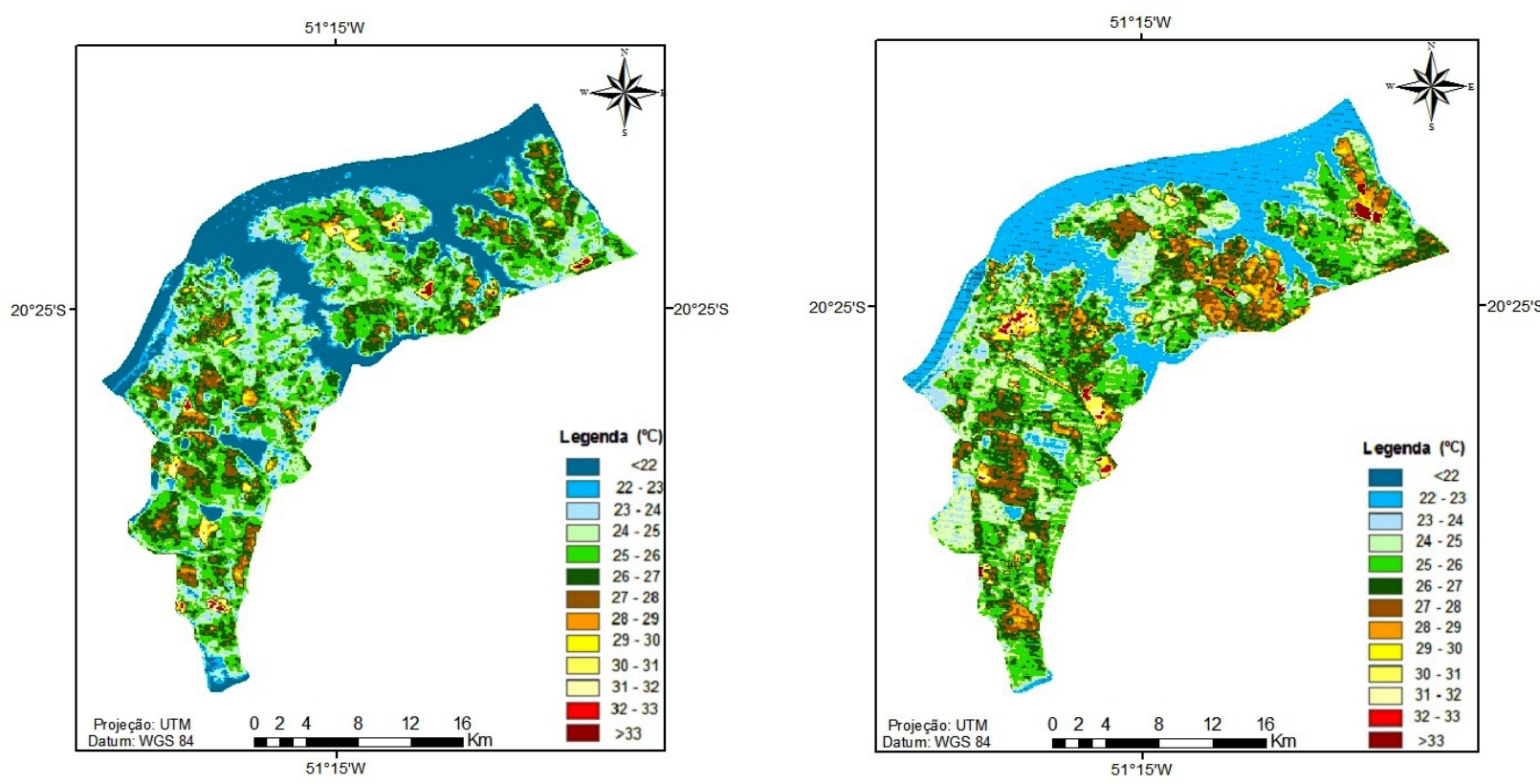

Figure 5 - Classified image of the estimated Surface Temperature for (a) 13/May/2000 and (b) 10/April/2011

Table 5 - Distribution of surface temperature values (in \%) for 13/May/2000 and 10/April/2011

\begin{tabular}{c|c|c|c|c|c|c|r} 
& \multicolumn{7}{c}{ Surface Temperature $\left({ }^{\circ} \mathrm{C}\right)$} \\
\cline { 2 - 8 } $\mathrm{T}$ & $<22$ & $22-23$ & $23-24$ & $24-25$ & $25-26$ & \multicolumn{2}{c}{$26-27$} \\
\hline 2000 & 24 & 4,8 & 10,3 & 13,9 & 24,1 & \multicolumn{2}{|c}{13,1} \\
\hline 2011 & 2,9 & 19 & 7,1 & 18,3 & 21 & \multicolumn{2}{c}{14,1} \\
\hline $\mathrm{T}$ & $27-28$ & $28-29$ & $29-30$ & $30-31$ & $31-32$ & $32-33$ & $>33$ \\
\hline 2000 & 6,1 & 1,9 & 0,6 & 0,5 & 0,6 & 0,2 & 0,1 \\
\hline 2011 & 10,6 & 4,3 & 1,1 & 0,8 & 0,7 & 0,3 & 0,5
\end{tabular}

The difference between the mean temperatures was $0.7^{\circ} \mathrm{C}$ (increase of $2.8 \%$ ), the minimum rose $3.2^{\circ} \mathrm{C}(18 \%)$ and the maximum $6.1^{\circ} \mathrm{C}(17.7 \%)$, in other words, for both days analyzed there was an increase in temperature values. On both dates, sites with water presented the lowest temperature value among the classes. This occurs, most likely, due to its high specific heat $\left(1 \mathrm{cal} / \mathrm{g}^{\circ} \mathrm{C}\right)$, which requires a large amount of energy to change its temperature. In turn, the increase in the mean temperature values is noteworthy, which rose from $22^{\circ} \mathrm{C}$ to $22^{\circ} \mathrm{C}-23^{\circ} \mathrm{C}$. This may be due either to natural causes or by the silting of riverbeds, which would diminish the water line and hinder heat dissipation. Observing the images, the lowest temperature values occurred in areas that presented denser vegetation cover and, in contrast, locations with exposed soil and anthropized areas presented the highest temperature values. Below, figure 6 shows the comparative histogram of Surface Temperature frequencies for the days under study. 


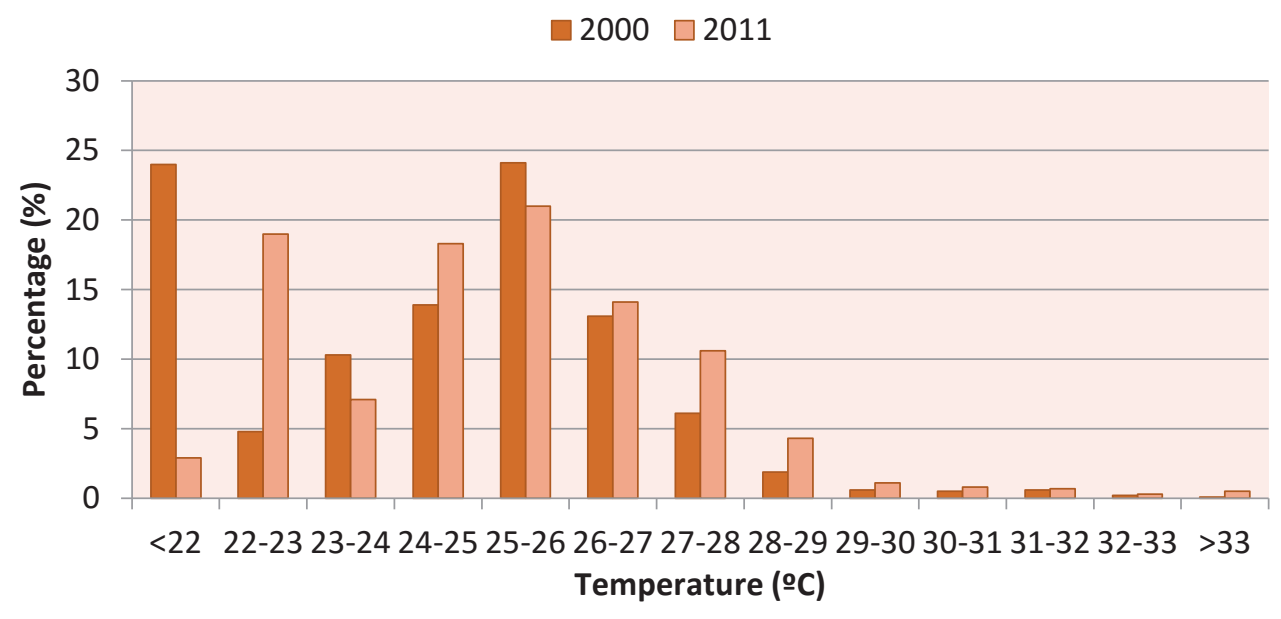

Figure 6 - Comparative histogram of surface temperature frequencies for both images used

\section{b) Soil heat flux}

For May 13, 2000, the values found for soil heat flux had a mean of 48.4 W.m-2, a minimum of 0.9 W.m-2, a maximum of 62.9 W.m-2 and a standard deviation of \pm 4.3 . In turn, April 10, 2011, presented mean values if $58.0^{\circ} \mathrm{C}$, a maximum of $89.3 \mathrm{~W} . \mathrm{m}-2$, a minimum of $1.2 \mathrm{~W} . \mathrm{m}-2,88.1 \mathrm{~W} . \mathrm{m}-2$, and a standard deviation of 6.1 W.m-2. Table 6 shows the values collected for the days under study.

Table 6 - Values of soil heat flux (in W.m-2) (minimum, maximum, mean and standard deviation) for May 13, 2000 and April 10, 2011

\begin{tabular}{ccccc}
$\begin{array}{c}\text { Date } \\
\text { 13/05/2000 }\end{array}$ & Minimun & Maximun & Mean & Standard Deviation \\
\hline $10 / 04 / 2011$ & 1,2 & 89,9 & 48,4 & 4,3 \\
\hline
\end{tabular}

For the region of Conquista/MG, Andrade (2008) obtained mean values for soil heat flux of $81.91 \mathrm{~W} / \mathrm{m}^{2}$, a minimum of $45.66 \mathrm{~W} / \mathrm{m}^{2}$, and a maximum of $269.47 \mathrm{~W} / \mathrm{m}^{2}$. For exposed soil, the same author found values between $50 \mathrm{~W} / \mathrm{m}^{2}$ and $100 \mathrm{~W} / \mathrm{m}^{2}$, for sugarcane of $50 \mathrm{~W} / \mathrm{m}^{2}$ to $250 \mathrm{~W} /$ $\mathrm{m}^{2}$ and, for water, values ranging between $150 \mathrm{~W} / \mathrm{m}^{2}$ and $300 \mathrm{~W} / \mathrm{m}^{2}$. Silva and Bezerra (2005), while studying the region of Petrolina/PE and Juazeiro/BA found values for water surface areas from $211.80 \mathrm{~W} / \mathrm{m}^{2}$ to $214.50 \mathrm{~W} / \mathrm{m}^{2}$ and, for soil heat flux, between $94.50 \mathrm{~W} / \mathrm{m}^{2}$ and $112.30 \mathrm{~W} / \mathrm{m}^{2}$. Mendonça (2007), studying the northern part of Rio de Janeiro, obtained mean values of soil heat flux from $31.90 \mathrm{~W} / \mathrm{m}^{2}$ to $96.51 \mathrm{~W} / \mathrm{m}^{2}$ for the months of fall/winter and for spring/summer from $72.93 \mathrm{~W} / \mathrm{m}^{2}$ to $43.69 \mathrm{~W} / \mathrm{m}^{2}$. According to this author, lower values appear in wetter areas and higher values appear in urban areas and in those devoid of vegetation.

Figure 7(a) and table 7 show the values found for soil heat flux on May 13, 2000. The interval of greater occurrence was the one that ranged between $45 \mathrm{~W} / \mathrm{m}^{2}$ and $50 \mathrm{~W} / \mathrm{m}^{2}$, with $36.7 \%$ of the occurrences. The second most frequent interval was the light green colored, with flux from $50 \mathrm{~W} / \mathrm{m}^{2}$ to $55 \mathrm{~W} / \mathrm{m}^{2}$. The areas with water were classified in grey and had values under $45 \mathrm{~W} / \mathrm{m}^{2}$, answering for $24.8 \%$ of the occurrences. There were no values greater than $65 \mathrm{~W} / \mathrm{m}^{2}$. The zone between the values $60 \mathrm{~W} / \mathrm{m}^{2}$ and $65 \mathrm{~W} / \mathrm{m}^{2}$, the light red color, only had $0.5 \%$ of occurrences.

Figure 7(b) and table 7 show the behavior presented by soil heat flux for April 10, 2011. In this image, it can be seen that the interval with the highest value was from $55 \mathrm{~W} / \mathrm{m}^{2}$ to $60 \mathrm{~W} / \mathrm{m}^{2}$, which answered for $41.2 \%$ of the occurrences and is represented by the color orange. The second largest occurrence was colored red, from $60 \mathrm{~W} / \mathrm{m}^{2}$ to $65 \mathrm{~W} / \mathrm{m}^{2}$, answering for $20.6 \%$ of the data. Areas with water were classified in orange with values between $50.0 \mathrm{~W} / \mathrm{m}^{2}$ and $55.0 \mathrm{~W} / \mathrm{m}^{2}$, answering for $19.4 \%$ of the occurrences. The smallest interval found was for values between $85 \mathrm{~W} / \mathrm{m}^{2}$ and 90 $\mathrm{W} / \mathrm{m}^{2}$, answering for $0.1 \%$ of the occurrences 

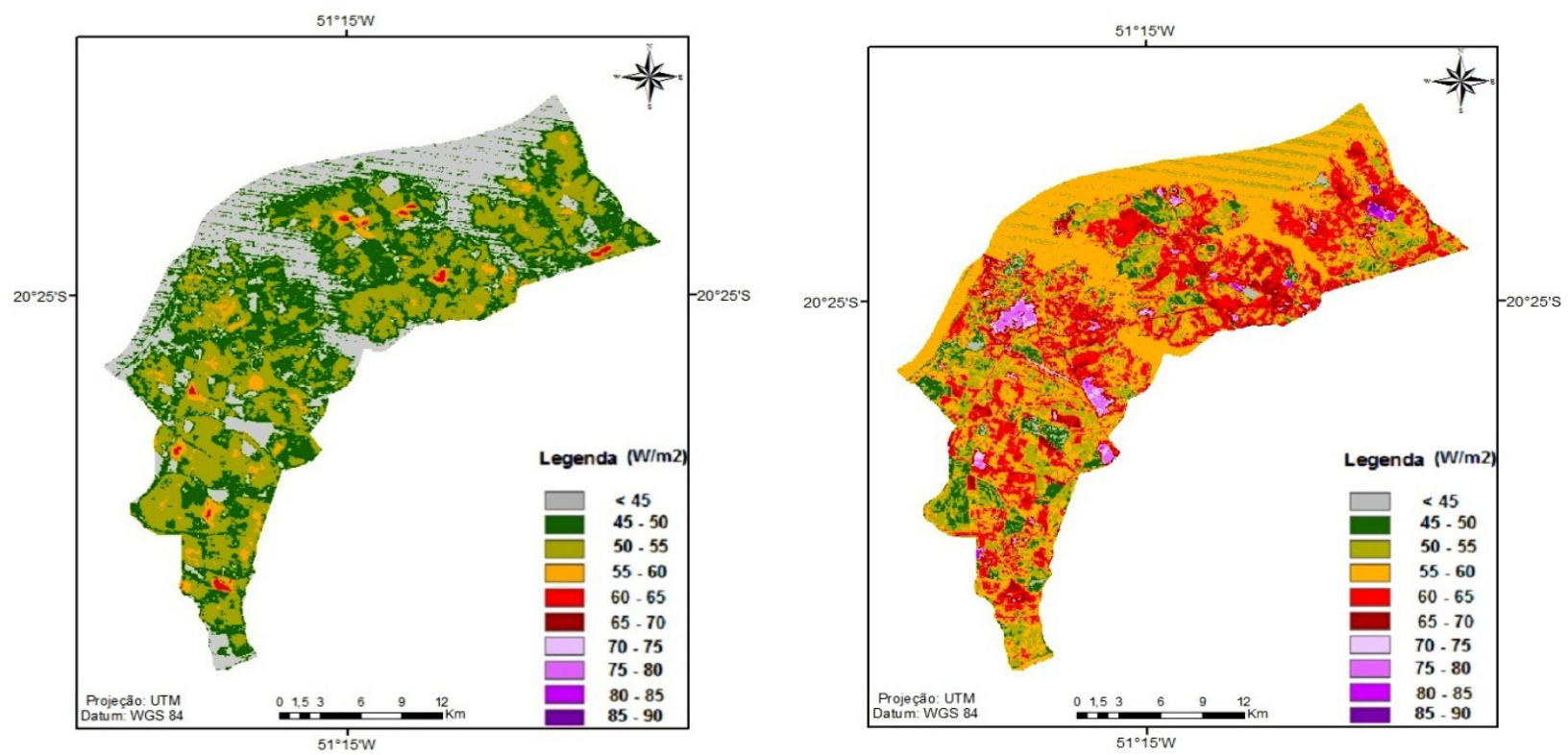

Figure 7 - Classified image of soil heat flux estimated for (a) 13/May/2000 and (b) 10/April/2011

Table 7 - Distribution of soil heat flux values (in \%) for 13/May/2000 and 10/April/2011

\begin{tabular}{cc|cccccccccccc} 
& \multicolumn{10}{c}{ Soil Heat Flux } \\
\cline { 3 - 11 } & \multicolumn{1}{c}{$<$} & $45-50$ & $50-55$ & $55-60$ & $60-65$ & $65-70$ & $70-75$ & $75-80$ & $80-85$ & $85-90$ \\
\hline 2000 & 25 & 36,7 & 34,7 & 3,3 & 0,5 & 0 & 0 & 0 & 0 & 0 \\
\hline 2011 & 1,4 & 6,9 & 19,4 & 41,2 & 20,6 & 7,1 & 1,8 & 1,2 & 0,3 & 0,1
\end{tabular}

The values for soil heat flux were a minimum of $3.5 \%$, a mean of $29.5 \%$ and a maximum of $21.5 \%$. Observing the spatialization of the soil heat flux, it is possible to perceive lower values in wetter areas (hydric bodies or vegetation with water retention) and higher ones in urban areas and in areas devoid of vegetation. In the cutout, the increase in soil heat flux, abrupt in some regions, indicates the occurrence of heat islands. This occurs because without vegetation cover the exposed soil has a high thermal amplitude, rapidly heating up during the day and increasing heat irradiation and the temperature in its surroundings. This warming can be easily seen in the images because of the time at which they were collected, 12:57:50 for 13/May/2000 and 13:11:53 for 10/April/2011, with a strong solar incidence over the surface. Below, Figure 8 shows the comparative histogram of soil heat flux frequencies for both images used. 


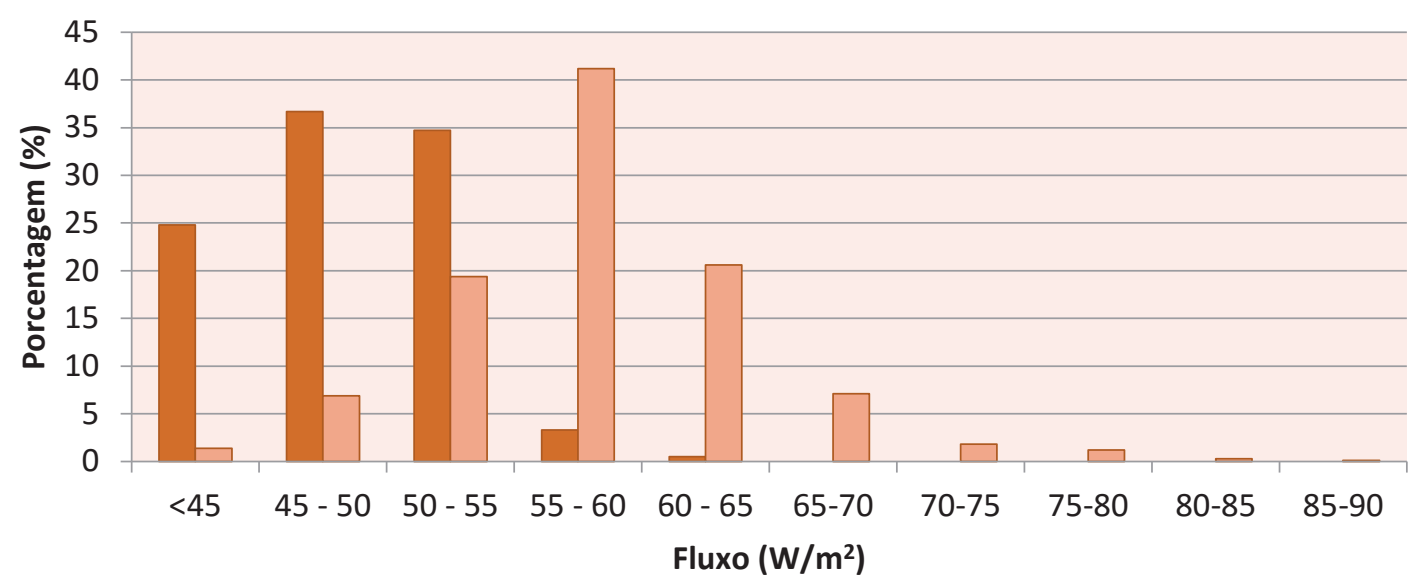

Figure 8 - Comparative histogram of soil heat flux frequencies for both images used

\section{FINAL CONSIDERATIONS}

The use of remote sensing allowed the identification of differences in spatial and temporal patterns in response to soil use and occupation, and natural phenomena in regions close to rivers and their areas of influence.

In this study, the analysis of a small area proved to be advantageous, because it allowed the monitoring and comparison of changes in soil heat flux, surface temperature and albedo in the region of Ilha Solteira/SP, by means of estimates made from images collected by TM - Landsat 5, for two days, with an interval of 10 years between captures.

There was an increase in surface temperature, albedo and soil heat flux for the region of Ilha Solteira/SP. In the case of soil heat flux, this increase entails the emergence of heat islands, a phenomenon connected to the urbanization of the environment. In turn, the increase of the albedo and of surface temperature is indicative of modifications in the region's vegetation cover, whether due to the suppression of native forests or the substitution of previously used agricultural crops.

The generated maps (surface temperature, soil heat flux and albedo) offer data with potential use by the general public and public authorities. They can also be used by NGOs that deal with urban planning and the formulation of public policies on infrastructure and environmental health, aiming to provide quality of life to the local population as well as assist in the planning of agro-pastoral activities for the region of Ilha Solteira.

\section{BIBLIOGRAPHIC REFERENCE}

ALLEN, R.; BASTIAANSSEN, W.; WATERS, R.; TASUMI, M.; TREZZA, R. Surface energy balance algorithms for land (SEBAL), Idaho implementation - Advanced training and users manual, version 1.0, 97p. 2002.

ARYA, S. P. Introduction to Micrometeorology . North Carolina: Academic Press, 1998.

BASTIAANSSEN, W.G.M. Regionalization of surface flux densities and moisture indicators in composite terrain. Ph. D. Thesis, Wageningen Agricultural. University, Wageningen, The Netherlands, 1995. BASTIAANSSEN, W. G. M. SEBAL - based sensible and latent heat fluxes in the irrigated Gediz Basin, Turkey. Journal of Hydrology, v.229, p.87-100, 2000. 
BIAS, E.S.; BAPTISTA, G.M.M.; LOMBARDO, M.A.; Análise do fenômeno de ilhas de calor urbanas, por meio da combinação de dados landsat e ikonos. SIMPÓSIO BRASILEIRO DE SENSORIAMENTO REMOTO, 11, Belo Horizonte. Anais... São José dos Campos: INPE, 2003. p.1741 - 1748. 2003.

CASTRO, B. L.; FREITAS FILHO, E.; SILVA, L. R.; SANTIAGO, L. S.; INVENÇÃO, M. S. Avaliação da supressão da vegetação e aumento da temperatura em áreas agrícolas do Oeste Baiano entre os anos de 1990 e 2010 por meio dos dados LANDSAT/TM. SIMPÓSIO BRASILEIRO DE SENSORIAMENTO REMOTO, 16. (SBSR), 2013, Foz do Iguaçu. Anais... São José dos Campos: INPE, 2013.

CHANDER, G.; MARKHAM, B. Revised Landsat-5 TM Radiometric Calibration Procedures and Postcalibration Dynamic Ranges. IEEE Transactions on Geoscience and Remote Sensing, v, 41, n. 11, 2003.

COELHO, A. C. P. Agregação de novas variáveis ao processo de planejamento urbano e regional sob a perspectiva de gestão dos recursos hídricos. Curitiba. Dissertação (Curso de Pós-Graduação em Engenharia de Recursos Hídricos e Ambiental) Setor de Tecnologia, Universidade Federal do Paraná. 2004.

COSTA, D. F.; PERES, L. F.; SILVA, R. S. Identificação de ilhas de calor na área urbana de Ilha Solteira-SP através da utilização de geotecnologias. XIV SIMPÓSIO BRASILEIRO DE SENSORIAMENTO REMOTO, 2009, Natal. Anais... Natal, RN: INPE, p.647-653. 2009.

FERREIRA, M.E.; ANDRADE, L. R. M.; SANO, E.E; CARVALHO, A. M. Uso de processadores de imagens digitais na avaliação da taxa de cobertura doo solo. CONGRESSO BRASILEIRO DA CIENCIA DO SOLO, 28., 2001, Londrina. Ciência do solo: Fator de produtividade competitiva com sustentabilidade;[resumos]. Londrina: Sociedade Brasileira de Ciência do Solo:Embrapa Soja, p. 284. 2001.

FREITAS LIMA, E.A.C. Estudo da paisagem do Município de Ilha Solteira SP: subsídios para o planejamento físico ambiental. São Carlos, 107p. Tese (Doutorado em Ciências) - Centro de Ciências Biológicas e da Saúde, Universidade Federal de São Carlos. 1997.

GARTLAND, L. Heat islands: understanding and mitigating heat urban areas. Published by Earthscan. UK and USA. 215p. 2008.

GODOY, L. B; BAPTISTA, G. M. M; ALMEIDA, T. Relação entre vegetação e temperatura de superfície nos parques urbanos do Distrito Federal, por meio de dados ASTER. In: SIMPÓSIO BRASILEIRO DE SENSORIAMENTO REMOTO, 14, 2009. Natal. Anais... São José dos Campos: INPE, p. 699 - 705, 2009.

GOMES, H. F., SILVA, B. B. da, CAVALCANTI, E. P., ROCHA, H. R. Balanço de radiação em diferentes biomas no estado de São Paulo mediante imagens Landsat 5. Geociências, v.28, p.153-164, 2009.

HUETE, A. R. Soil influences in remotely sensed vegetation-canopy spectra. Theory and Applications of Optical Remote Sensing. 1 ed. New York, Ed. John Wiley \& Sons. 1989.

IBGE - Instituto Brasileiro de Geografia e Estatística, 2007, IBGE Cidades, contagem populacional 2007, Disponível em: http://www.ibge.gov.br/cidadesat/default.php, Acesso em 31 de janeiro de 2008.

LIMA, R. C. Identificação das ilhas de calor na cidade de Campo Grande/MS utilizando o sensoriamento remoto. 2008, 69f. Trabalho de Conclusão de Curso (Graduação em Geografia Bacharelado) - Universidade Federal do Mato Grasso do Sul, Aquidauana, 2008.

LOPES, P.M.O.; VALERIANO, D.M. validação do albedo de superfície terrestre obtido dos dados do sensor MODIS em regiões montanhosas.Anais do XIII Simpósio Brasileiro de Sensoriamento Remoto. Florianópolis, Brasil, INPE, p. 2805-2812. 2007.

MARKHAM, B. L., BARKER, L. L. "Thematic mapper bandpass solar exoatmospherical irradiances", International Journal of Remote Sensing, v. 8, n. , pp. 517 - 523. 1987.

MASHIKI, M.Y.; Geoprocessamento na identificação de ilhas de calor e influência do uso e ocupação do solo na temperatura aparente da superfície no município de Botucatu/SP. 67p. Dissertação de Mestrado em Agronomia/Energia na Agricultura - Faculdade de Ciências Agronômicas, Universidade Estadual Paulista. Botucatu-SP. 2012.

MENDONÇA, J. C.; FREITAS, R. M.; SOUSA, E. F. Avaliação temporal dos eventos de inundação da Baixada Campista, Região Norte Fluminense, RJ, pelo uso de imagens digitais orbitais do sensor MODIS. Revista Brasileira de Cartografia, Rio de Janeiro, v. 59, n. 03, p. 249/4-253, 2007.

PMIS, PREFEITURA MUNICIPAL DE ILHA SOLTEIRA, Disponível em: $<$ http://www.ilhasolteira.sp.gov. br/?option=com_content\&view=article\&id=1\&Itemid=2>. Acesso em 20.05.2014. 
QUERINO, C. A. S.; MOURA, M. A. L.; LYRA, R. F. da F.; MARIANO, G. L. Avaliação e comparação da radiação solar global e albedo com ângulo zenital na região amazônica. Revista Brasileira de Meteorologia, v.21, n.3a, 42-49, 2006.

SELLERS, W.D. Physical Climatology. University of Chicago. Chicago Press, Chicago, Illinois. 1969.

SILVA, H.R. Avaliação dos principais fatores do meio físico do município de Pereira Barreto, SP, relacionado com a produção agropecuária, mediante o emprego de imagens aéreas. Ilha Solteira, 74p. (Relatório do projeto de pesquisa apresentado para a Comissão Permanente de Regime de Trabalho com o fim de ser desenvolvido durante o período de estágio probatório), 1991. 
Surface Temperature and Albedo in The Itha Solteira Region, São Paulo 
GOMES, H. B.; CAVALCANTE, L. B.; SILVA JUNIOR, R. S.; SANTOS, M. N. 
Surface Temperature and Albedo in The Itha Solteira Region, São Paulo 